\title{
Kabbalah and Knowledge Transfers in Early Modernity: Foreword
}

\author{
Agata Paluch and Patrick B. Koch
}

This issue stems from a collective scholarly attempt to interrogate the fashioning and evolution of the many forms of Kabbalah, understood as a literary, religious, and intellectual phenomenon in early modern Europe, from the perspective of the contemporary knowledge-making processes. It originated in an European Association of Jewish Studies (EAJs) conference held in July 2019 at the Free University (FU) of Berlin and the Selma Stern Zentrum für Jüdische Studien Berlin-Brandenburg (zJS), and co-hosted by the University of Hamburg. The conference's initial objective was to recognize and evaluate the part that kabbalistic literatures, in a variety of their written formats, played in the transfer of knowledge in the early modern world, a subject that has only recently begun to attract scholarly attention. The practical and scientific dimension of early modern kabbalistic literature exerted a significant influence on both Jewish and non-Jewish intellectual culture, and was widely disseminated in early modern Europe. From the sixteenth up to the eighteenth centuries, these various facets of kabbalistic literatures gripped numerous reading audiences who aimed to gain and systematize knowledge of the metaphysical world, and to harness its power to effect changes in the physical world. The conference gathered participants to contribute a series of case studies to help critically reassess the role and consequences of printed texts in the spread of esoteric ideas and practices, and to re-evaluate the character and significance of thriving manuscript culture, in its variegated material forms, for the early modern transmission of knowledge. The 2019 conference thus focused on contextualized readings of primary texts presented with the aim to highlight variant patterns in the diffusion of kabbalistic traditions, especially those formulated in Safed, Palestine, in new cultural and changing historical circumstances, showcasing their role in the formation and transformation of contemporary knowledge systems.

The results of this collaborative effort are presented in the current issue, which follows three overlapping themes. First, it spotlights the material organization of kabbalistic knowledge and the role of media in the communication 
and dispersing of mystical and kabbalistic traditions. Secondly, it focuses on the literary organization of kabbalistic knowledge and its transmission in different genres and within variant epistemic contexts. Lastly, it zooms in on the movement of kabbalistic knowledges that were enabled by the circulation of people, texts, and objects across cultural, historical, and linguistic contexts. In looking at the transmission of kabbalistic knowledge, the articles in this issue highlight the often blurred boundaries between categories, taxonomies, or disciplines of knowing - including those referred to as "esoteric" and "mystical," to which modern readers are often accustomed. They emphasize the shifts, often multiple, in meanings of kabbalistic ideas and practices contained in texts as they were translated, edited, and appropriated within new literary, linguistic, material, and cultural settings of early modern Europe. In doing so, this special issue stays mainly, although not exclusively, within the geographical parameters of Europe and the transfers of knowledge within the larger European kabbalistic culture between the sixteenth and eighteenth centuries. It also underscores a multidirectional dynamic of knowledge circulation by re-assessing the role of the center of kabbalistic learning and the source of its authority in the Land of Israel vis-a-vis local European traditions and forms of knowing in fashioning new genres and models for communicating and performing kabbalistic knowledge.

By looking at selected case studies, we have tried to examine the ways in which Kabbalah attracted the attention of many Jewish and non-Jewish practitioners, readers, and aficionados in the early modern period, all of whom may have become active agents in shaping both local and trans-regional kabbalistic expertise. Our issue opens with the questions of the agency of an individual in the processes of transmission and reception of knowledge(s). In her article, Magdalena Jánošíková focuses on Eliezer Eilburg (c. 1530-c. 1580) and explores the web of traditions contained in two manuscript miscellanies copied by him, following their intellectual trajectory from the territories south of the Alps to East-Central Europe. In her reading, the kabbalistic traditions served as a channel for the sixteenth-century savant to act in accordance with contemporary medical guidelines as they constituted part of the science of the period, and thus shaped the individual's lived experience. Hanna Gentili's article concerns an autograph manuscript belonging to Yohanan Alemanno (c. 1435-c. 1504), a handwritten commonplace book that contains a wide variety of Hebrew sources, ranging from logic and the philosophy of language to ethics and psychology. By analyzing the disposition of the textual material in the manuscript notebook, often precisely identified by the scribe, Gentili shows how philosophical and kabbalistic sources that were presented side-by-side on the notebook's page merged in Alemanno's later works. 
The transformation of kabbalistic texts due to translations, migrations, forgeries, or economic exchanges - voluntary or not - with the literary and material consequences of these processes, is the subject of the articles by Saverio Campanini, Flavia Buzzetta and J. H. Chajes. Saverio Campanini traces a long history of (mis-)reading and (mis-)recognizing the attribution of one kabbalistic commentary that has continued in contemporary scholarship. In his diligent and trailblazing reading of a variety of source materials, Campanini emphasizes the use of Hebrew manuscripts alongside Christian printed books in reconstructing the history of kabbalistic textual transmission as well as of kabbalistic historiography. Flavia Buzzetta examines the transmission, adaptation, and transformation of Jewish thought in relation to Christian works through a detailed study of the kabbalistic library of Pierleone da Spoleto (1455-1492). Buzzetta focused especially on the Sicilian translations of kabbalistic texts and argues that Spoleto's translation of kabbalistic texts can be understood as adaptations and transformations of kabbalistic knowledge, a type of "intellectual hybrids" characteristic of his time and place. J. H. (Yossi) Chajes reflects on the intellectual background of Jacob Șemah (c. 1578-1667), a physician-kabbalist born to a converso family in Portugal, and his later kabbalistic self-fashioning in the new intellectual context of Jerusalem. As Chajes argues, Semah's remarkable impact on the seventeenth-century and later kabbalistic culture should be placed in the broader context of the Portuguese educational curriculum that molded Șemah into a Jewish humanist.

The literary development of kabbalistic genres of texts in the context of nascent print is the focus of the article by Andrea Gondos. She focuses on the emergence and rising popularity of kabbalistic encyclopedias and anthologies that were devised to pursue systematic methods for coping with the multiplicity of textual sources in early modernity. Emphasizing the material aspects of manuscripts, Gerold Necker presents the systematizing principles that underlie Moses Zacuto's (c. 1610-1697) works of reference. Necker traces Zacuto's practical approach to kabbalistic material and showcases the methods of ordering of many kabbalistic texts that Zacuto deployed initially in his notebooks to later build a more comprehensive textbook of Kabbalah. Avinoam J. Stillman follows the editorial strategies applied to a medieval text, Sha'arei Orah, dubbed a primer of kabbalistic knowledge, in the changing context of Central and Eastern Europe. Gondos's, Necker's and Stillman's articles analyze the impact of media (both manuscript and print), in shaping and broadcasting esoteric texts to new audiences and in new intellectual climates. The matter of print as a new medium for the transfer of kabbalistic traditions is also the subject of Giulio Busi's intervention, which concludes the present issue. It focuses on the knowledge routes between Italy and the Polish-Lithuanian 
Commonwealth and reflects on how the diffusion of printed kabbalistic texts has influenced and transformed Kabbalah as a form of knowledge.

This special issue invites reflections on a role that Kabbalah has played in transmitting and legitimizing knowledge in early modernity in both Jewish and non-Jewish societies. Among various early modern Jewish audiences, Kabbalah became one of the dominant languages through which individuals and groups could express and authorize their views and beliefs on subjects ranging from law to natural knowledge. This authoritative language was often shared with members of non-Jewish circles interested in various forms of prisca theologia in the fifteenth and sixteenth centuries, or esotericism in the seventeenth and eighteenth centuries. The various forms and methods of the transmission of kabbalistic knowledge across material and textual genres and across linguistic and cultural areas in the early modern period certainly still call for further studies and comparative discussions. We hope that this special issue of the European Journal for Jewish Studies will invite further scholarly inquiries into the various modes and means of kabbalistic knowledge transfers.

\section{Acknowledgments}

As the guest editors of this special issue, we would like to express our thanks to all of the contributors for their willingness to present and publish their work as part of this project. We are also particularly grateful to the director of the Institute for Jewish Studies at the Free University of Berlin, Prof. Giulio Busi, for his enthusiasm for our collaborative project, as well as to the Selma Stern Zentrum für Jüdische Studien Berlin-Brandenburg (zJs) for hosting us on the second day of the conference in Berlin. Furthermore, we would like to express our thanks to Silvia Musseleck at the FU Berlin, as well as to Nadia Fiensch, Dr. Manja Herrmann, and Dr. Monika Schärtl at ZJs for their support in the preparation and implementation of the initial event. It has been a great honor to publish the proceedings of a conference funded by the European Association of Jewish Studies in the association's own journal. With the European Journal of Jewish Studies, this issue has certainly found a most adequate home. We would like to thank EJJS Editor Prof. Giuseppe Veltri, Katelyn Chin and Brenda Kaldenbach from Brill, as well as Lies Meiboom and Elisa Thiele for their productive cooperation. Within the framework of this project, we were also able to create synergies between our two Emmy Noether groups: "Patterns of Knowledge Circulation: The Transmission and Reception of Jewish Esotericism in Manuscript and Print in Early Modern East-Central Europe" and "Jewish Moralistic Writings of the Early Modern Period." We are therefore especially grateful to the German Research Foundation (DFG) and its generous support of our academic work. 